\title{
Taiwanese Grade-Five Students Reading a Chinese Science Text of Mixed Sub-Genres: A Misce Analysis Study
}

\author{
Yueh-Nu Hung ${ }^{1, *}$ \\ ${ }^{1}$ School of Humanities, National Taichung University of Education, Taichung, Taiwan \\ *Correspondence: School of Humanities, National Taichung University of Education, 140 Min-Sheng Road, \\ Taichung, Taiwan. Tel: 886-4-2218-3845. E-mail: yuehnu@ms3.ntcu.edu.tw
}

Received: December 1, 2014

Accepted: December 10, 2014 Online Published: January 23, 2015

doi:10.5430/jct.v4n1p30

URL: http://dx.doi.org/10.5430/jct.v4n1p30

\begin{abstract}
This study aimed to understand Taiwanese grade-five students' reading of a science text with mixed sub-genres based on their oral reading miscues. Twenty students participated in the study. Each of the one-on-one interviews started with a reader profile interview followed by oral reading of a Chinese science text and retelling. Miscue data were analyzed based on the classroom procedure of the Reading Miscue Inventory. Analyses were conducted to explore differences in the participants' reading of two paragraphs of an expository sub-genre and a narrative sub-genre. The study showed that the quantity and quality of miscues differed in the two different sub-genres within the science text. Students showed higher confidence and better comprehension when reading the narrative sub-genre. Implications for reading instruction are discussed.
\end{abstract}

Keywords: genre; miscue analysis; reading comprehension; science text

\section{Introduction}

The purpose of this study was to understand Taiwanese grade-five students' reading of a science text with mixed sub-genres based on their oral reading miscues. The two sub-genres investigated were narration and exposition. Specifically The study wanted to understand whether students' reading comprehension and possible difficulties vary in different portions of a science text due to genre difference. In what follows, the background and rationale of the research is explained from three different aspects.

First, science education is highly valued in a world that is so science and technology dependent. Science for all and scientific literacy are important goals that science educators aim to achieve. The importance of reading in learning science is well recognized (Davies \& Greene, 1984; Osborne, 2002, 2003; Yore \& Treagust, 2006). Students engage in thinking, arguing, clarifying, and summarizing via language and reading in science classes. Some children love to read science texts more than stories (Granowsky, 2004; Moss, 2005). Science texts are a genre by themselves and the information load is often quite heavy. Zwiers (2008, p. 85-86) talked about seven characteristics of science language, which are: (1) Describe relationships of taxonomy, comparison, cause and effect, hypothesis, and interpretation. The text structure is dense and hierarchical. (2) Describe procedures explicitly with procedural language. (3) Connect abstract ideas illustrated by various media. (4) Use generalized verbs in the present tense to describe phenomena. (5) Be highly objective. There is a lack of first-person perspective and emotion. (6) Use large amounts of passive voice construction. (7) Use many new and big words with new meanings, many of which are nominalizations. Science reading comprehension is a challenge for students who are accustomed to reading narrative text. Therefore, science text reading is a needed and important area of research.

Second, the integration of reading instruction and science education is a research area that is receiving great attention in both the reading field and the science education field. In 2010, Science published a special issue on science, reading, and literacy. In the introduction of the special issue, Hines, Wible, and McCartney (2010) wrote that "good literacy skills make it easier to learn science, but science topics can also be used to teach literacy skills that will translate well to other subjects" (p. 447).

Many instructional strategies have been developed by science educators and researchers to include literacy 
instruction in the science curriculum (see, for example, Brozo \& Flynt, 2007; Fang, 2006; Romance \& Vitale, 1992; Saul, 2002). Yore, Craig and Maguire (1998) clearly stated that students' understanding of their reading processes is one of the future directions in science reading research. Yore and his colleagues (2004) also reiterated the importance of critical thinking and language in future science reading research. On the side of reading research, educators and researchers have been studying content reading for decades, and many instructional innovations have been developed to teach reading science texts (see, for example, Manning \& Manning, 1995; Ogle, 1986; Ogle \& Correa-Kovtun, 2010; and works by Guthrie and his colleagues on Content Oriented Reading Instruction). It is believed that reading comprehension should not be an end by itself, but a means for the learning of different subjects, for gaining knowledge, and for becoming literate in different disciplines. Recent attempts at integrating reading instruction and science education raise more basic questions about students' science reading processes, such as available and unfamiliar strategies, and other reading difficulties resulted from science text structures.

For example, in the Taiwanese educational context, Chi (1999) said more than a decade ago that Taiwanese grade-six children's comprehension of narrative texts was better than that of expository texts. In Hung, Chin, and Liao's (2010) study on Taiwanese elementary science teachers' perceptions of science reading instruction, they found that the surveyed science teachers had quite ambiguous understanding about the comprehension processes involved in reading science and non-science texts. Chang and Lin (2001) found that seventh-graders' most often used strategy for handling unfamiliar scientific words was breaking them apart into separate characters. It would be crucial to investigate what other strategies children use and what difficulties they encounter when they read science informational texts.

Third, science texts are represented by a wide range of text types. The dichotomous terms of "narration" and "exposition" or "fiction" and "nonfiction" are not sufficient to show the complexity of genres and sub-genres of science texts. The lump term "informational text" does not fulfill the purpose, either. Brooks and Warren (1972) pointed out that it could be difficult to label texts with traditional terms like exposition, narration, persuasion and so forth. Doiron (1995) also argued that nonfiction actually contains different text types. While Ebbers (2002) argued that the richness of genres in science texts is beneficial for students to learn different scientific thinking and inquiry processes, she also cautioned that the line for distinguishing different genres in science text is not always clear. Considering the fact that science texts are usually complex with different text types, the author wonders whether student's reading performance varies when reading science texts of different genres.

In sum, reading science text helps to promote scientific literacy and advance student's reading proficiency and there is a pressing need for more research on science reading. The author is keenly aware of the complexity of genres in science texts and aspires to understand how student's reading performance might differ when reading science texts with mixed sub-genres in them.

Against this background the current study was conducted. Taiwanese grade-five students were asked to read a science text with different sub-genres in it, and the quantity and quality of these students' reading miscues were examined to understand their reading performance and comprehension on the whole text and on two of the sub-genres, the expository and the narrative sub-genres.

\section{Method}

Reading miscue analysis research method was adopted. The history of miscue analysis can be traced back to more than a half century ago. Any deviances between a reader's read aloud and the expected responses to print could be considered mistakes or errors due to carelessness or laziness on the part of the reader, but miscue analysis takes a different view. Goodman (1996) has argued that the same linguistic processing explains both successful reading and miscues. Miscues are results of misuses of language cues, and hence the name "miscues."

By analyzing oral reading miscues, we come to see what linguistic cues (graphophonic, syntactic or semantic) are used, what meaning is constructed, and what predictions and inferences are made by the reader. For example, the substation of cheese for chess in the sentence "Johnny likes to play chess." indicates a high reliance on graphic and sound cues in reading. The miscue "cheese" creates a grammatical sentence "Johnny likes to play cheese." but the meaning is probably strange in the context of the text. If no correction is made, the miscue is taken as an indication of weakness in semantic processing.

Most reading assessments, especially standardized reading comprehension examinations, test the result of reading, not the process of reading. Educators have always known that for any assessment to provide information to feed into and improve teaching, we need more than just a score. Miscue analysis is an alternative reading research and 
assessment tool that provides valuable and authentic information on the reader's meaning construction at the time of reading (Hung, 2012). Miscue analysis research method was chosen because this study did not only want to know the result of comprehension but also the processes, difficulties, and strategies of the participants' reading of the science text. In what follows, the participants, reading material, data collection procedure, and data analysis are briefly explained.

\subsection{Participants}

Grade-five elementary students were recruited for the study because students at this age have begun to read extensively for both school and non-school purposes. A total of twenty students, seven girls and thirteen boys, who attended an urban public elementary school in central Taiwan participated voluntarily with parental consent. The reading ability of the participants was not controlled because this study did not intend to compare reading performance within or beyond the intact group. The Burke Reading Interview (Burke, 1980; Goodman, Watson \& Burke, 1987, 2005) was modified and questions about science reading materials, habits, and difficulties were added to the interview. Each of these students was internviewed one-on-one with this modified version of the Burke Reading Interview guide in order to understand their habits and perceptions of reading.

\subsection{Reading Materials}

According to the Reading Miscue Inventory (Goodman, Watson, \& Burke, 1987, 2005), reading materials selected for miscue research must be real, authentic and have a connected discourse. The science text 害羞的含羞草 Hai Xiu De Han Xiu Cao (The Shy Mimosa) (Guan Zhi Wen Hua, 1986) was chosen for the current research because its mixed sub-genres represented the kind of popular children's science text that this study intended to investigate. It was selected from a volume, called "Interesting Plants," in a series of children's science trade books written in traditional Chinese characters and published in Taiwan. The series is called Tong Hua Lie Che ("Fairy Tale Train") and consists of twelve volumes in total. Other volumes in this series cover topics like garden plants, the human body, outer space, physics, and so forth. In 2004, this series was listed by the Government Information Office of Taiwan as the recommended high-quality readings for elementary and junior high school students. In this recommendation list, this series was recommended for elementary higher grade (grade-five and -six) and junior high school (grade-seven to -nine) students.

One change made to the reading text was that the phonetic symbols accompanying each Chinese character were deleted. Since Chinese is not a phonographic language, Chinese characters in texts for young children are usually accompanied by phonetic symbols. In Taiwan, Chinese text in school textbooks from grade-1 to -4 is accompanied by phonetic symbols. From grade- 5 and above, the phonetic symbols are removed. The participating readers in this study were fifth-graders already and most of their reading inside and outside the school did not have phonetic symbols. Furthermore, if they encountered characters that they were not able to read aloud without the help of phonetic symbols, it would be informative to observe how they dealt with the reading problem.

The text contains a total of 786 Chinese characters that are written vertically from the top to the bottom of the page. It explains the biological features of the plant, mimosa, why the leaves and stems droop when stimulated, how Taiwanese farmers in the past used it to predict weather, and how it was brought to Taiwan. Among the seven paragraphs in the text, some are quite informational, explaining the physical features and the biological facts, whereas some others are more like narratives describing how farmers used them to predict weather and how the Dutch brought them to Taiwan around 300 years ago from South America. Even the title, "The Shy Mimosa," is interesting because the plant is personified. Figure 1 shows an excerpt of the text with English translation in the figure caption. This excerpt clearly shows that the text adopts a child-friendly tone to explain a science concept. 


\begin{tabular}{|c|c|c|c|c|c|}
\hline 到 & 含 & 。 & 到 & 呢 & 端 \\
\hline 暴 & 羞 & 例 & 很 & $?$ & 的 \\
\hline 屈 & 草 & 如 & 多 & 其 & , \\
\hline 雨 & 就 & 狂。 & 危 & 惯 & 虎 \\
\hline 的 & 會 & 風 & 臉 & का & 什 \\
\hline 侮 & 䞡 & 基 & , & , & 度 \\
\hline 害 & 快 & 雨 & 所 & 造 & - \\
\hline 。 & 把 & 来 & 以 & 是 & 喽 \\
\hline 小 & 莱 & 卧 & 它 & 因 & 它 \\
\hline 閒 & 子 & 的 & 們 & 禹 & 就 \\
\hline 友 & 合 & 晓 & 也 & 植 & 會 \\
\hline P & 䫓 & 读 & 就 & 物 & Ih \\
\hline , & 起 & , & 想 & 生 & 呢 \\
\hline 你 & 來 & 㓮 & 出 & 長 & $?$ \\
\hline 㟋 & , & - & - & 在 & 是 \\
\hline 含 & 追 & 閒 & 些 & 野 & 不 \\
\hline 筑 & 样 & 始 & 方 & 外 & 是 \\
\hline 草 & 才 & 酸 & 法 & , & 它 \\
\hline 是 & 比 & 凰 & 来 & 常 & 点 \\
\hline 不 & 校 & 或 & 保 & 常 & 的 \\
\hline 是 & 不 & 下 & 放 & 合 & 很 \\
\hline 很 & 弇 & 雨 & 自 & 遭 & 害 \\
\hline 聴 & 受 & , & 己 & 遇 & 基 \\
\hline
\end{tabular}

Figure 1. Reading Material Example

Description: This is an excert of the reading material. It is read vertically from top to bottom and from right to left. This is the English translation: Young children, you might now wonder why the leaves of the mimosa fold up when they are touched. Are they really very shy? As a matter of fact, plants that grow in the wild often encounter dangers and therefore they come up with ways to protect themselves. For example, in a severe storm, the mimosa quickly folds up their leaves when the wind or rain begins so that they can avoid being damaged by the storm. Young children, don't you think the mimosa is very smart?

Among the seven paragraphs of the text, paragraphs four (hereafter P4) and seven (P7) were selected for in depth analysis. P4 was considered an example of an expository sub-genre. It has 135 characters in four sentences and it offers the scientific explanation of the folding and drooping of the leaves. This paragraph explains that when the leaves are touched or stimulated, the water stored in the cells at the base of the petiole, a region called pulvinus, moves to the top side of the stalk so that the bottom side of the stalk shrinks while the opposing top side swells. This change in pressure causes the petioles to bend at their pulvinus. The concept is new for the participants of the study, and so are several vocabulary words. P7 has 139 characters in five sentences and it talks about how the plant was brought by the Dutch to Taiwan 300 years ago. Elements in narratives like people, events, time, and place are presented in this paragraph. These two paragraphs were chosen to compare possible differences in reading performance among the participating students. Please see the appendix for the English translation of the two paragraphs.

\subsection{Data Collection}

Data collection sessions were conducted on a one-on-one basis in a meeting room at the participants' school. Each student was first interviewed before they started reading aloud The Shy Mimosa. After the oral reading, unaided and aided retelling followed. In the unaided retelling, the readers were asked to freely retell the contents of the text as they understood and remembered it. Then, in the aided retelling, questions were asked to check the reader's comprehension of the content and science concepts based on a retelling guide. Following the suggestions of the Reading Miscue Inventory (Goodman, Watson, \& Burke, 2005) on the preparation of a retelling guide or outline for expository texts, the retelling guide of this study included three types of questions: specific information, generalizations, and major concepts. A science education professor and a veteran elementary school science teacher helped to check and revise questions on the retelling guide. Each individual data collection session took around 45 minutes, and all sessions were audio- and video-recorded for analysis purpose. Signed parent consent forms were obtained from all readers.

\subsection{Data Analysis}

Miscue data were analyzed following the classroom procedure of miscue analysis (Goodman, Watson \& Burke, 2005). Due to orthographic features of the Chinese writing, modifications were made in the coding of Chinese miscues. It would require a separate paper to simply discuss how the modifications were made to analyze Chinese miscue data; it is also beyond this paper's scope to discuss how the nature of the Chinese orthography might influence the types and quantity of miscues produced by Chinese readers. However, for the purpose of this current 
study, a few major modifications and examples are provided for the interested reader.

First, characters, instead of words, are the unit of analysis. This has to be so because Chinese words are composed of characters. In earlier Chinese miscue analysis studies, character instead of word is commonly used as the unit of analysis (Hung \& Lin, 2010; Wang, 2006).

Second, judgment on graphic similarity was mainly based on the construction and components of the expected response (what was in the text) and the observed response (what the reader produced in oral reading). The number and the configuration of the strokes in the concerned characters are also considered. Instead of "high," "some," and "no" as the three judgments of graphic similarity for English miscues, "similar" and "not similar" were used in Chinese. Two other judgments, "heteronomy" and "not coded," were added because of the high percentage of heteronyms (the same character with different pronunciations and different meanings) in Chinese. Chinese is also rich in homophones, and sometimes it's very difficult to decide which homophone is read and understood for a specific syllable. In such case, "not coded" is the judgment. Table 1 shows examples of each of the four graphic similarity judgments.

Table 1. Examples of the Four Judgments of Graphic Similarity

\begin{tabular}{|c|c|c|c|}
\hline & Expected Response & $\begin{array}{l}\text { Observed } \\
\text { Response }\end{array}$ & Note \\
\hline Similar & $\begin{array}{l}\text { 含羞草很普遍 , 應該 } \\
\text { 到處都可以找得到。 } \\
\text { pian4 }\end{array}$ & $\begin{array}{l}\text { 通 } \\
\text { tongl }\end{array}$ & $\begin{array}{l}\text { Both characters have this } i \text { component on the left. The } \\
\text { number of strokes, } 13 \text { and } 11 \text {, are close. }\end{array}$ \\
\hline Not Similar & $\begin{array}{l}\text { 你說含羞草是不是很 } \\
\text { 聰明呢? } \\
\qquad \text { shuol }\end{array}$ & $\begin{array}{c}\text { 們 } \\
\text { men2 }\end{array}$ & The components within the characters do not look alike. \\
\hline Heteronym & $\begin{array}{c}\text { 很整齊的排列成兩行 } \\
\text { hang } 2\end{array}$ & $\begin{array}{l}\text { 行 } \\
\text { xin2 }\end{array}$ & $\begin{array}{l}\text { The expected response is a noun meaning "row" or "line" } \\
\text { while the observed response is a verb meaning "to move" } \\
\text { or "to execute." It is the same written character, but the } \\
\text { pronunciation and the meaning are different. }\end{array}$ \\
\hline Not Coded & $\begin{array}{l}\text { 這是因為植物生長在 } \\
\text { 野外 } \\
y i e 3\end{array}$ & bi4 & $\begin{array}{l}\text { Chinese is rich in homophones. There are more than } 20 \\
\text { characters that can be pronounced bi4. From the context of } \\
\text { the surrounding characters and words in this sentence and } \\
\text { the entire text, it was difficult to decide which character } \\
\text { was read aloud and understood by the reader. Therefore } \\
\text { the graphic similarity for this miscue was not coded. }\end{array}$ \\
\hline
\end{tabular}

Third, judgment on phonological similarity was based on the onset, rime, and tone of the expected and the observed responses. Three judgments were coded: similar, not similar, and heteronym. In Chinese, a character is always one syllable. The two characters (the expected reading and the miscue) must have the same onset or rime to be considered phonologically similar. Table 2 shows examples of each of the three phonological similarity judgments.

Table 2. Examples of the Three Judgments of Phonological Similarity

\begin{tabular}{|c|c|c|c|}
\hline & Expected Response & $\begin{array}{l}\text { Observed } \\
\text { Response }\end{array}$ & Note \\
\hline Similar & $\begin{array}{c}\text { 就表示天氣將要晴朗 } \\
\text { jiang1 }\end{array}$ & $\begin{array}{c}\text { 就 } \\
\text { jiu4 }\end{array}$ & $\begin{array}{l}\text { The two syllables have the same onset and nucleus } \\
\text { sounds. }\end{array}$ \\
\hline Not Similar & $\begin{array}{c}\text { 這是因為植物生長在 } \\
\text { 野外 } \\
\text { shi4 }\end{array}$ & $\begin{array}{l}\text { 個 } \\
\text { ge }\end{array}$ & The two syllables differed in onset, rime, and tone. \\
\hline Heteronym & $\begin{array}{c}\text { 很整齊的排列成兩行 } \\
\text { hang2 }\end{array}$ & $\begin{array}{c}\text { 行 } \\
x i n 2\end{array}$ & $\begin{array}{l}\text { If a miscue is coded "heteronym" in graphic } \\
\text { similarity, it must be also "heteronym" in } \\
\text { phonological similarity. }\end{array}$ \\
\hline
\end{tabular}


A final note regarding the modifications of the coding and analysis of Chinese miscues concerns the definition of what counts as a sentence in Chinese. In this study, a sentence is defined by a period. Chinese sentence structures are quite different from those of English, and linguists commonly describe Chinese as a topic-comment language (Li \& Thompson, 1976, 1981). However, to make the analysis of Chinese miscues more accessible and friendly for classroom teachers, the author chose to count periods instead of making linguistic judgments on how many topic-comment units there are in a reading text. The author also believes that how sentences are defined and counted would not matter as long as miscue data across different texts are not compared. It is fine to examine and compare miscues of different readers who read the same text.

The marking and coding of miscue data was conducted and split between two well trained research assistants. The author checked and confirmed the marking and coding. This analysis pattern was followed for the analysis of syntactic and semantic acceptability, meaning loss, corrections, graphic and phonological similarity, types of character-for-character substitution, and numbers of miscues per hundred characters (MPHC).

The readers' retelling, both unaided and aided, was transcribed verbatim. A research assistant and the author worked together and assigned a both-agreed comprehension score to each reader based on their unaided and aided retelling. Comprehension scores for paragraphs four and seven were decided in the same way based on the readers' responses to specific questions from these two paragraphs.

\section{Results}

In what follows, the miscues produced by the participants for the entire text are reported and discussed, followed by those miscues that occurred in P4 and P7.

The participating readers made an average of 2.6 miscues per hundred characters and $24 \%$ of the miscues were corrected, either successfully or not. $93 \%$ of the sentences, with miscues and all corrections, were grammatically acceptable while $91 \%$ were semantically acceptable. Language sense, which was determined by the number of sentences without meaning loss out of sentences that were judged semantically acceptable, was $92 \%$. In character-for-character substitution miscues, both graphic and phonological similarity were low $(27 \%$ and $24 \%$, respectively), which was one of the characteristics in Chinese miscue data (Hung \& Lin, 2010; Wang, 2006). While these numbers can be considered good according to miscue analysis research literature, the average comprehension score was 68 out of 100, which was not a strong indication of comprehension. Overall, the author had the impression that the participants tried to follow and read aloud the text as closely as possible but their comprehension did not match their read aloud performance.

Pearson's correlation tests were conducted to examine the possible relationships among various factors in these participants' reading of the text, including the above mentioned miscue statistics plus reading time and the participants' science and Chinese language arts grades from the previous semester. The only significant correlation found was between the number of miscues and reading time $(r=.523, p=.018)$, which was obvious. The more miscues a reader made, the more time it took to finish reading the text. This proved what Flurkey and Goodman (2004) said, "Miscue analysis research has shown it is not the number of miscues a reader produces that is most important, but the quality of the miscues..." (p. 237).

Table 3 shows the miscue data for the entire text and for P4 and P7. The data suggested that the participants performed better in reading P7. They made more miscues in P4, and the sentences they read in P4 had slightly lower syntactic acceptability, semantic acceptability, and language sense. Correction rate in P4 was higher (24\% vs. $13 \%)$. Most importantly, the comprehension score in P4 was a lot lower than that of P7 (42 and 72, respectively). 
Table 3. Miscue Data of the Whole Text, Paragraph 4, and Paragraph 7

\begin{tabular}{lccc}
\hline & Whole Text & Paragraph 4 & Paragraph 7 \\
\hline Number of characters & 786 & 135 & 139 \\
Number of sentences & 26 & 4 & 5 \\
Number of miscues* & 406 & 94 & 61 \\
MPHC** & 2.6 & 3.5 & 2.2 \\
Syntactic acceptability & $93 \%$ & $91 \%$ & $95 \%$ \\
Semantic acceptability & $91 \%$ & $89 \%$ & $95 \%$ \\
Graphic similarity & & & \\
$\quad$ Similar & $27 \%$ & $32 \%$ & $42 \%$ \\
$\quad$ Dissimilar & $68 \%$ & $68 \%$ & $54 \%$ \\
$\quad$ Heteronym & $1 \%$ & $0 \%$ & $4 \%$ \\
$\quad$ Not coded & $3 \%$ & $0 \%$ & $0 \%$ \\
Phonological similarity & & & \\
$\quad$ Similar & $24 \%$ & $18 \%$ & $13 \%$ \\
$\quad$ Dissimilar & $75 \%$ & $82 \%$ & $83 \%$ \\
$\quad$ Heteronym & $1 \%$ & $0 \%$ & $4 \%$ \\
Language sense & $92 \%$ & $80 \%$ & $84 \%$ \\
Correction rate & $24 \%$ & $24 \%$ & $13 \%$ \\
Comprehension & 68 & 42 & 72 \\
\hline
\end{tabular}

*This is the total number of miscues made by the 20 participants.

**MPHC stands for the number of miscues per hundred characters.

Then the types of miscues produced in these two paragraphs were examined. In P4 where the reason for the folding and drooping of leaves was explained, 26 (28\%) miscues occurred in nouns, or more exactly, in special terms related to parts of the plant. On the contrary, in P7, only 8 (13\%) miscues occurred in nouns or noun phrases. Moreover, when these 26 special-term-related miscues in P4 were examined more closely, it was found that 23 of them were related to leaves or parts of the leafstalk. For example, 19 occurred in the nouns or noun phrases for "pulvinus," "the top of pulvinus" or "the bottom of pulvinus." Figure 2 shows an example of such miscue. In short, in the expository sub-genre of the text, students made a higher concentration of miscues on nouns or noun phrases, especially those specific and central to the subject content of the text.

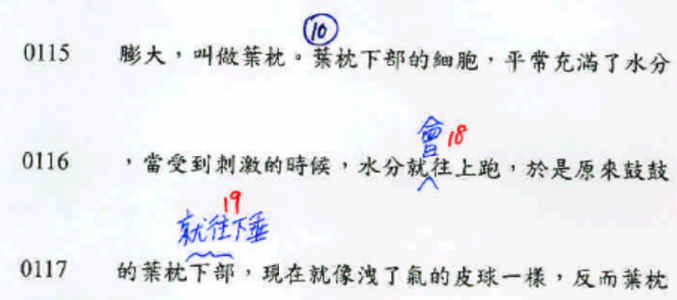

Figure 2. Miscue Examples

Description: An example of miscues on words about parts of the plant in paragraph 4. In miscue number 19, the reader changed the noun phrase "the bottom of pulvinus" to a verb phrase "the pulvinus droops."

Last, the participants' retelling from P4 and P7 were compared. While the majority of the students knew that the reason for the folding and drooping of mimosa leaves had to do with water, only two out of the 20 readers could correctly describe the moving of water from cells on the bottom of the pulvinus to the top of the stalk as the cause for the drooping. The rest of the participants could only say something very vague or even incorrect. For example, a student said in the retelling that the leaves folded up because the water in the plant moved to the leaves. Another said water was collected from the tips of the leaves. Still another said it was because the water in the plant disappeared. A boy told us in a matter-of-fact tone that muscular dystrophy was the cause for the folding of mimosa leaves. It will be intriguing to explore why and how students came up with these responses. For the purpose of this study, these students' retelling showed that the majority of the readers did not truly or fully understand the scientific explanation presented in P4. In Graesser, León, and Otero's (2002) terms, these readers had shallow knowledge but failed to build deep knowledge from this reading event.

In contrast, the participants' retelling about P7 was quite correct and complete. Most students were able to identify 
key information. They also understood that because of Taiwan's warm and pleasant weather, the mimosa stayed and started to grow on all parts of the island. It was observed that when recounting the contents of this paragraph, the readers were less hesitant and they showed more confidence in their retelling.

In summary, miscue data showed that these students read the expository sub-genre with more difficulties and less proficiency. The narrative sub-genre was read more easily with good comprehension. The quantitative miscue analysis data also supported this statement.

The reader profile interview data were analyzed inductively and several important findings about these readers' understanding about reading and their uses of reading strategies were revealed. First, reading was generally considered enjoyable. Only two students said they did not like reading, and only four (the aforementioned two readers included) said they did not like reading science texts.

Second, their definition of what a good reader is was tied to oral reading performance and school grades. When asked who they knew was a "good reader," they mentioned the name of a girl who often represented the class to take part in read aloud contest. They also mentioned the names of classmates whose school grades were on the top of the class. This suggested that their understanding of what reading means and what reading comprehension is was not mature.

Third, when asked what they did to overcome reading difficulties, they unanimously mentioned two strategies: look up in the dictionary and ask people for help. When the author pushed the question further by saying that no dictionaries were at hand and no other people were around, most of them replied they would wait till the teacher or family members were available to help them. Only two students said they would guess what the text said. These responses clearly showed that the readers had a very limited number of reading comprehension strategies. It could also be the case that they were not metacognitively aware of what reading strategies they knew and used. Also, it is obvious that the readers were not flexible in reading and how they solve reading difficulties. This observation was confirmed by the fact that the readers did little to amend comprehension problems in their read-aloud of The Shy Mimosa.

\section{Discussion}

Based on the miscue and retelling data, findings about reading generally and about the reading of science texts with multiple and mixed sub-genres specifically are discussed below. First, this study is a confirmation of a very well and widely documented phenomenon; namely, elementary school readers have more experiences reading narratives. The term the fourth-grade slump describes the difficulties in reading non-narrative texts for students around that grade level (Chall \& Jacobs, 1983; Street \& Snow, 2003). The elements of narratives such as people, time and place, difficulties, and solutions are close to life experiences (Fang, 2006). Narratives also make up the largest amount of materials for young readers. On the contrary, expository texts, or the science text of this study, have unique linguistic features and cognitive demands. Reading proficiency and strategies that were developed from reading narratives do not automatically transfer to the reading of expository texts. Students who are proficient readers of narratives do not necessary read science expository texts with the same degree of comfort. This is an important understanding for science teachers who emphasize reading as a medium for learning in the inquiry based science curriculum.

Second, this study found that within a single text, the participating readers' reading performance varied when reading different sub-genres. This observation presents a challenge for the widespread yet erroneous idea that a reader's performance is more or less constant throughout a text. In other words, a proficient reader will read throughout a text quite fluently and smoothly while a less proficient reader will have a stop-and-go kind of reading performance. This study found that the participants' reading performance varied in different parts of the text. This finding echoes Flurkey's (1998) research where he argued that reading rate or reading flow is a sign of the complex and dynamic reading process. He explained that more efficient readers are more flexible at using various strategies to achieve comprehension and thus show greater variability in reading rate. This study is also a direct support for Flurkey and Goodman's (2004) study where they examined a grade-four student's reading of Magic School Bus at the Waterworks (Cole, 1986), a book they called a fictionalized documentary, with multiple sub-genres. Flurkey and Goodman reported that "patterns of miscues shift across each genre or type within the entire text" (2004, p. 234). This is also what this study found. These studies support that reading is a complex, dynamic, and flexible process where the reader is actively using available linguistic cues and cognitive strategies to make sense of the text.

Third, the author agrees with Flurkey and Goodman's (2004) statement that encountering multiple genres within a text is by itself not a cause for reading difficulty. They have explained that the linguistic features of the text and the 
cognitive demand of the content being addressed are what make a text easy or difficult to read for a specific reader. In science reading, how much a reader already knows about the topic is as equally, if not more strongly, indicative of the depth of comprehension as his or her reading ability (Afflerbach, 1986; McNamara \& Kintsch, 1996). In this study, P4 was comparatively difficult for the readers because of the scientific terms and nominalize forms as well as the abstract scientific explanation of plant biology. Walpole (1998/1999) said that the fastest growing area in children's books is the informational text, and these books come in a wide variety of text types. To make the matter even more complex, it's hard to draw the line to separate various genres and sub-genres (Ebbers, 2002). It is unnatural to talk about and teach reading as if the texts are pure in terms of genre. Language and reading teachers need to keep in mind that a lot of what we ask students to read is complex in genre types, and mixed genres within a text are very common. The reader's familiarity with the genre and the content explains their reading performance, not the complexity of genres itself.

The last point of discussion concerns the kinds of support teachers can provide to help readers to improve science reading comprehension. In the miscue collection sessions of this study, it was noticed that the participants very rarely sought to correct comprehension problems when reading P4, not at least outwardly or observably. In other words, the readers didn't pause to think, read back, stop to summarize or fix a comprehension problem, even though they were instructed to try their best to understand the text and not just to read aloud. "This is not a read aloud performance," they were told. One might argue that these readers probably felt pressured to continue reading in the context of miscue analysis research. That might be true, but still some types of problem solving behaviors in P4 were expected. This is a group of children that knew little about comprehension strategies, and the reader profile interview data confirmed this. They told the author in the interview that when encountering reading difficulties, they most often asked people or consult a dictionary for help. Based on the reading behaviors observed in this study, it is suggested that teachers teach students to monitor comprehension when reading science texts. A strategy as simple as stopping at the end of each paragraph and ask themselves what they have and have not understand will help to identify and correct comprehension problems. The following instructional strategies are also suggested to enhance students' reading comprehension: activating and sharing related prior knowledge before reading, providing teacher explanation and demonstration during reading, and conducting class discussion after reading. While research on comprehension strategy instruction abound, these instructional strategies are suggested because they help the reader to move from the self and the text itself to working with and obtaining assistance from the more knowledgeable others.

\section{Conclusion}

This study examined Taiwanese grade-five students' reading of a Chinese science text of mixed sub-genres with miscue analysis research method. Results clearly showed that the participants' miscues changed quantitatively and qualitatively between P4, a more expository type of sub-genre, and P7, a more narrative type of sub-genre. Students were more confident and showed better comprehension when they read P7.

Only 20 readers were involved and they read only one text. The two paragraphs that represented the two sub-genres investigated in this study were also quite short. Another limitation is that little information about how the participating students read expository and narratives types of texts was collected and therefore it is difficult to examine how their reading perpormances in this study could be explained by their reading habits. These are limitations of the current study. Nevertheless, this preliminary study in the reading of Chinese science text with sub-genres clearly shows to the reading research and instruction community that science reading is quite complex. Reading is an important medium for learning science, yet science texts often contain linguistic features and science concepts that are usually unfamiliar to young readers. Reading teachers and science teachers need to know the linguistic features of science texts, the cognitive demand of the text, and the reader's language and background knowledge in order to understand the complexity and dynamics of reading generally and reading science text specifically. It's also suggested that assistance and teaching from outside the reader and the text itself, such as prior knowledge activation, discussion, and comprehension monitoring, be provided to maximize student's learning of science through reading.

\section{Acknowledgements}

This study was supported by research grant awarded by the National Science Council (NSC 98-2511-S-142-010-MY3 and NSC 101-2410-H-142-012-My2) of Taiwan. 


\section{References}

Afflerbach, P. (1986). The influence of prior knowledge on expert readers' importance assignment. In J. A. Niles \& R. V. Lalik (Eds.), National reading conference yearbook, 53. Solving problems in literacy: Learners, teachers and researchers (pp. 30-40). Rochester, NY: National Reading Conference.

Brooks, C., \& Warren, R. P. (1972). Modern rhetoric. New York: Harcourt Brace.

Brozo, W. G., \& Flynt, S. (2007). Content literacy: Essential toolkit elements. The Reading Teacher, 61(2), $192-194$. http://dx.doi.org/10.1598/RT.61.2.9

Burke, C. (1980). The reading interview: 1977. In B. P. Farr \& D. J. Stricker (Eds.), Reading comprehension: Resource guide. Bloomington, IN: School of Education, Indiana University.

Chall, J. S., \& Jacobs, V. A. (1983). Writing and reading in the elementary grades: Developmental trends among low SES children. Language Arts, 60, 617-626.

Chang, H.-L., \& Lin, C.-Y. (2001). Xue Tong Yan Zhong De Ke Xue Zhuan You Ming Ci [Scientific terminology in the eyes of school children]. Chinese Journal of Science Education, 9(3), 219-234.

Chi, P.-H. (1999). Guo Xiao Xue Tong Yue Du Li Jie Neng Li Zhi Feng Xi [Written text comprehension in school-age children]. Journal of Elementary Education, 11, 100-133.

Cole, J. (1986). The magic school bus at the waterworks. New York: Scholastic.

Davies, F., \& Greene, T. (1984). Reading for learning in the sciences. Edinburgh, UK: Oliver \& Boyd.

Doiron, R. (1995). An aesthetic view of children's nonfiction. English Quarterly, 28(1), 35-41.

Ebbers, M. (2002). Science text sets: Using various genres to promote literacy and inquiry. Language Arts, 80(1), 40-50.

Fang, Z. (2006). The language demands of science reading in middle school. International Journal of Science Education, 28(5), 491-520. http://dx.doi.org/10.1080/09500690500339092

Flurkey, A. (1998). Reading as flow: A linguistic alternative to fluency. Unpublished doctoral dissertation, University of Arizona, Tucson, Arizona.

Flurkey, A., \& Goodman, Y. M. (2004). The role of genre in a text: Reading through the waterworks. Language Arts, 81(3), 233-244.

Goodman, K. S. (1996). On Reading. Portsmouth, NH: Heinemann.

Goodman, Y. M., Watson, D. J., \& Burke, C. L. (1987). Reading miscue inventory: Alternative Procedures. New York: Richard C. Owen Publishers, Inc.

Goodman, Y. M., Watson, D. J., \& Burke, C. L. (2005). Reading miscue inventory: From evaluation to instruction (2nd ed.). New York: Richard C. Owen Publishers, Inc.

Graesser, A. C., León, J. A., \& Otero, J. (2002). Introduction to the psychology of science text comprehension. In J. Otero, J. A. León, \& A. C. Graesser (Eds.), The psychology of science text comprehension (pp. 1-15). Mahwah, NJ: Lawrence Erlbaum.

Granowsky, A. (2004). Get real! Young readers may be more apt to reach for content area readers about "real life" rather than narrative tales. Teaching Pre K-8, 34, 56-57.

Guan Zhi Wen Hua (1986). Hai Xiu De Han Xiu Cao [The shy mimosa]. Tong Hua Lie Che Zhi Wu Shi Jie 1 Qu Wei Zhi Wu (Ge Xin Ban) [Fairy tale trains, world of plants 1, interesting plants (Revised ed.)], (p. 42-43). Kaohsiung: Guan Zhi Wen Hua.

Hines, P. J., Wible, B., \& McCartney, M. (2010). Learning to read, reading to learn. Science, $328,447$. http://dx.doi.org/10.1126/science.328.5977.447

Hung, Y.-N. (2012). The validity and reliability of reading miscue analysis: Issues and possible consolidations. $H w a$ Kang English Journal, 18(1), 51-71.

Hung, Y.-N., \& Lin, H.-C. (2010). Guo Xiao Xin Zhu Min Zi Nu Guo Yu Wen Yue Du Biao Xian: Yue Du Cha Yi Fen Xi Ge An Yan Jou [Chinese reading performance of elementary school children of immigrant mothers: A reading miscue analysis case study]. Jiao Shi Zhi You [Teachers' Friend], 51(3), 2-12.

Hung, Y.-N., Chin, C.-C., \& Liao, S.-C. (2010). Guo Xiao Ke Xue Jiao Shi Dui Ke Xue Yue Du Zhi Ren Zhi Yu Jiao 
Xue [Elementary school science teachers' perceptions and instruction of science reading]. Dung Hai Jiao Yu Ping Lun [Tunghai Educational Review], 4, 94-126.

Li, C. N., \& Thompson, S. A. (1976). Subject and topic: A new typology of language. In C. N. Li (Ed.), Subject and topic (pp. 458-489). New York: Academic Press.

Li, C. N., \& Thompson, S. A. (1981). Mandarin Chinese: A functional reference grammar. Berkeley and Los Angeles, CA: University of California Press.

Manning, M., \& Manning, G. (1995). Reading and writing in the content areas. Teaching K-8, 26, 152-153.

McNamara, D. S., \& Kintsch, W. (1996). Learning from texts: Effects of prior knowledge and text coherence. Discourse Processes, 22, 247-288. http://dx.doi.org/10.1080/01638539609544975

Moss, B. (2005). Making a case and a place for effective content area literacy instruction in the elementary grades. The Reading Teacher, 59(1), 46-55. http://dx.doi.org/10.1598/RT.59.1.5

Ogle, D. (1986). KWL: A teaching model that develops active reading of expository text. The Reading Teacher, 39(6), 564-570. http://dx.doi.org/10.1598/RT.39.6.11

Ogle, D., \& Correa-Kovtun, A. (2010). Supporting English-language learners and struggling readers in content literacy with the "Partner Reading and Content, Too" routine. The Reading Teacher, 63(7), 532-542. http://dx.doi.org/10.1598/RT.63.7.1

Osborne, J. (2002). Science without literacy: A ship without a sail? Cambridge Journal of Education, 32(2), 203-218. http://dx.doi.org/10.1080/03057640220147559

Osborne, J. (2003). Examining the literacy component of science literacy: 25 years of language arts and science research. International Journal of Science Education, 25(6), 689-725. http://dx.doi.org/10.1080/09500690305018

Romance, N. R., \& Vitale, M. R. (1992). A curriculum strategy that expands time for in-depth elementary science instruction by using science-based reading strategies: Effects of a year-long study in grade four. Journal of Research in Science Teaching, 29(6), 545-554. http://dx.doi.org/10.1002/tea.3660290604

Saul, W. (2002). Science workshop: Reading, writing, and thinking like a scientist. Portsmouth, NH: Heinemann.

Street, A. P., \& Snow, C. E. (Eds.) (2003). Rethinking reading comprehension. New York: Guildford Press.

Walpole, S. (1998/1999). Changing texts, changing thinking: Comprehension demands of new science textbooks. The Reading Teacher, 52(4), 358-369.

Wang, S. (2006). A socio-psycholinguistic study on L2 Chinese readers' behavior while reading orally. Unpublished doctoral dissertation, University of Arizona, Tucson, Arizona.

Yore, L. D., \& Treagust, D. F. (2006). Current realities and future possibilities: Language and science literacyempowering research and informing instruction. International Journal of Science Education, 28(2-3), 291-314. http://dx.doi.org/10.1080/09500690500336973

Yore, L. D., Craig, M. T., \& Maguire, T. O. (1998). Index of science reading awareness: An interactive-constructive model, test verification, and grades 4-8 results. Journal of Research in Science Teaching, 35(1), 27-51.

Yore, L. D., Hand, B., Goldman, S. R., Hildebrand, G. M., Osborne, J. F., Treagust, D. F., \& Wallace, D. S. (2004). New directions in language and science education research. Reading Research Quarterly, 39(3), 347-352. http://dx.doi.org/10.1002/(SICI)1098-2736(199801)35:1<27::AID-TEA3>3.0.CO;2-P

Zwiers, J. (2008). Building academic language: Essential practices for content classrooms, grades 5-12. San Francisca, CA: Jossey-Bass.

\section{Appendix}

English translation of paragraph 4

Children, now you might wonder why the leaves of the mimosa move. Let's take a good look. The base of the petiole, an area called the pulvinus, is swollen big. The bottom of the pulvinus is usually filled with water cells. When the plant is stimulated, the water moves out of the cells to the top side of the pulvinus. The once swollen bottom part of the pulvinus is now flat like a deflated ball while the top part of the pulvinus is now inflated. This is why the petiole bends at the pulvinus and droops down. The same reason explains why leaflets fold up. 


\section{English translation of paragraph 7}

Children, the next time you have a chance to visit the countryside, look for the sign of the mimosa. They are quite common and easy to find. The mimosa is not native to Taiwan. It originates from South America. About 300 years ago they traveled with the Dutch to Taiwan. Since the weather in Taiwan is like spring all year round, the mimosa liked it a lot and decided to make it home. Very soon the offspring of the mimosa spreaded and settled in all parts of Taiwan. 